\title{
Experimental Study of the Operational Parameters on Low-cost Single-basin Solar Still in Jessore, Bangladesh
}

\author{
Biplob Kumar Biswas ${ }^{\mathrm{a}, *}$, Md. Abdul Halim ${ }^{\mathrm{a}}$, Shahanaz Parvin ${ }^{\mathrm{a}}$, Bablu Hira Mandal ${ }^{\mathrm{a}}$, Md. Wasikur \\ Rahman $^{\text {, }}$ Md. Jahangir Alama, Kh. Md. Shafiul Islam ${ }^{\mathrm{b}}$ \\ ${ }^{a}$ Department of Chemical Engineering, Jessore University of Science and Technology, Jessore- 7408 \\ ${ }^{\mathrm{b}}$ Department of Civil Engineering, Khulna University of Engineering and Technology, Khulna- 9203
}

\begin{abstract}
Keeping in mind the growing concern of sustainability, the present study aims to develop a hands-on technique for potable water production by using a portable single-basin solar still, which is constructed with low-cost, locally available and lightweight materials. The performance of single-basin solar still were investigated using different essential operational variables, which include weather condition, water salinity, brine water depth, and addition of glass marbles as energy absorbing material. Ambient weather conditions were found to have direct effect on the productivity of the still. The solar still productivity increased by $29 \%$ when a layer of glass marbles was used. The study also showed that the daily water production increased with the decrease in the initial depth of brine water. Estimating a useful life of 4 years of the solar still, an average cost of produced potable water was defined to be BDT 0.35 per lit. In addition, some important water quality parameters were tested and compared with drinking water standard values. The obtained values were found to be in line with the drinking water standards of WHO.
\end{abstract}

Keywords: Solar still; Distillation; Productivity; Water depth; Energy absorbing material.

\section{Introduction}

Bangladesh, having a population of more than 157 million, is one the most densely populated countries in the world [1]. Approximately $16.5 \%$ people in this country lack access to an improved water source. Besides, more than $80 \%$ of the total population of Bangladesh lives in low-lying land where monsoon floods contaminate water sources. Apart from that, water sources are very often polluted by chemical impurities and harmful organisms. It is also neither feasible to carry a huge amount of potable water on a regular basis nor possible to establish water distribution pipelines to the vulnerable communities because of insufficient infrastructures and economic predicament. As a result, the availability of safe drinking water has become a main problem for the communities who live in remote and hard-to-reach areas. To address this problem, researchers have been investigating since long and have proposed several sustainable and nonconventional technologies which include but not limited to rainwater harvesting [2-4] and solar distillation [5-7].

Being a tropical country, Bangladesh is recognized for reasonably high intensity of solar radiation, which can be utilized for drinking water production through the use of solar stills. Solar stills are mainly categorized into two distinct types namely active solar still and passive solar still. Water in the still undergoes direct heating in case of passive solar still whereas in case of active solar still; water undergoes heating by sunlight as well as by preheated water [8]. However, there are three different factors reported to affect the productivity of basin type solar stills: climatic, design and operational conditions. The climatic conditions include solar intensity, ambient temperature, wind velocity and so forth, while design conditions include type of stills, materials of construction, sun tracking system, inclination of cover etc. Operational conditions, on the other hand, mainly include water depth in the still, extent of salinity, addition of dye as well as energy absorbing materials [8,9]. Even though sunlight is an abundant source of energy and incurs a zero fuel cost, it requires more space as well as more equipment for collection [10]. Still it is considered as an economic and safe way of supply of pure water in remote and hard-toreach households who do not have access to potable water.

Numerous studies (both experimental and theoretical) have been reported analyzing design features, performance aspects of solar stills in the view to enhance productivity and sustainability. The effect of incident solar radiation on water productivity has already been well documented in many literatures [1116]. Very understandably it was the most affecting parameter on the solar still productivity because it directly affects the ambient temperature, which results a change in water temperature of the still and its vaporization. Nandi et al. [17] stockpiled the global radiation data of different cities of Bangladesh (including Jessore, the current research area) over the year (Fig. 1). It is evident that even though the global radiation rate is high in the period of February to June, the remaining period of the year also receives an average radiation rate of higher than $4 \mathrm{~kW} / \mathrm{m}^{2}$.day. AlHinai et al. [18] investigated performances of doubleeffect and single-effect solar still under different climatic, design and operational parameters in Oman and found $15.7 \%$ cost savings with double-effect solar still. Water depth $[19,20]$, inclination of cover [21], salt concentration [22], surfactant additives [23] and other effects [24] have been reported to improve the overall performance of solar stills. 


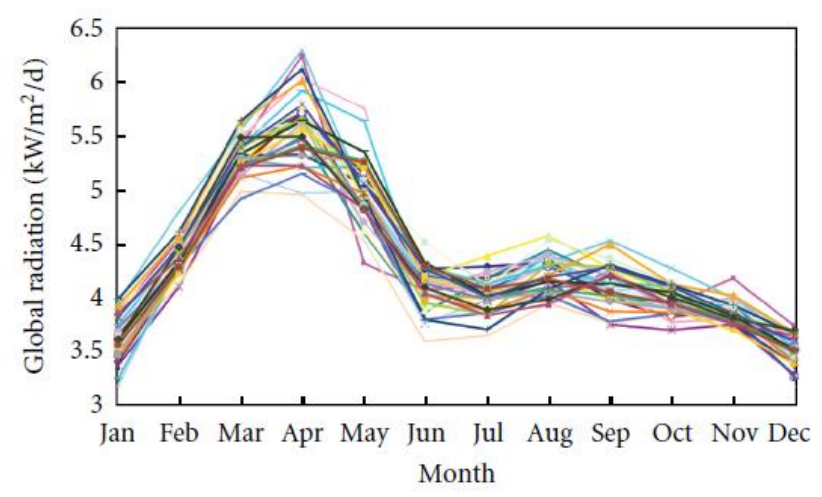

Fig. 1. Solar radiation over 31 cities (including Jessore) of Bangladesh [17].

The aim of the present study was to construct small, portable and low-cost single slope solar still to convert brackish water into potable water by using solar energy in remote and hard-to-reach areas in the context of Bangladesh. Moreover, different factors e.g. temperature, water depth, salt concentration etc. were investigated to find an improved performance as well as an increased production from the solar still in passive mode. Quality of the produced water also tested in the laboratory.

\section{Materials and Methods}

\subsection{Construction of single-basin solar still}

By using locally available materials, a low-cost solar still was constructed. It consisted of a rectangular basin made of wood plank $(16.0 \mathrm{~mm})$ and particle board (4.1 $\mathrm{mm}$ thick). The basin was of $60 \mathrm{~cm}$ length, $42 \mathrm{~cm}$ width and $10 \mathrm{~cm}$ height. Black polythene $(0.12 \mathrm{~mm}$ thick) was used as basin liner. Basin liner is a major part of solar still because it absorbs the incident radiation that is transmitted through the cover [25]. Black polythene used in this research not only minimized the cost of construction but also acted as an insulator at the same time. On this tray a frame of small wire $(3.8 \mathrm{~mm}$ diameter) was set and covered with transparent polythene $(0.09 \mathrm{~mm}$ thick) so that sunlight can be projected onto the brackish water. The average transmissivity of the transparent polythene cover was $0.71-0.73$ [26]. The frame can restrain the deformation of polythene cover. Tray and cover were constructed in such a way that the condensed water could drop down to a distillate channel from where water could be collected. The distilled water was collected in plastic bottles (insulated with rags) through plastic pipe. Once fabricated, the whole set-up could be moved easily from one place to another. The cross-sectional view of the constructed single-basin solar still is shown in Fig. 2.

\subsection{Working principle and Field test}

Brackish water was stored in the rectangular tray. The incident solar radiation transmitted through the

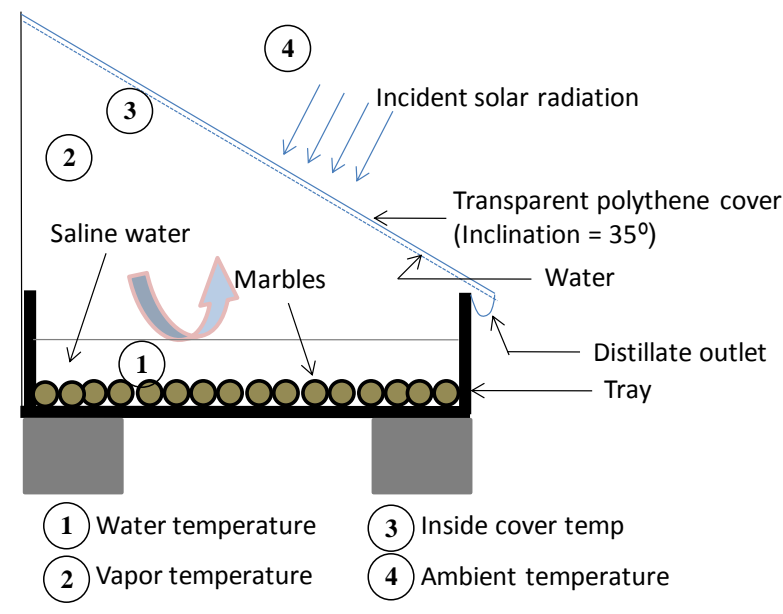

Fig. 2. Cross-sectional view of single-slope single-basin solar still with glass marbles

transparent polythene cover was absorbed by saline water, energy absorbing materials (if used) and the basin liner material. The energy absorbed at the base was largely transferred to the water in the still [27]. Thus the saline water was heated by solar radiation and only water was evaporated. The evaporative water vapor is transferred to the inner side of roof and wall surface and then condensed there by releasing the latent heat of vaporization. The condensed water flowed down along the surface due to gravity to distillate channel and collected in insulated bottle through pipe. The collected water was analyzed to determine $\mathrm{pH}$, turbidity, total dissolve dissolved solid, total hardness, chloride, iron, nitrate and alkalinity. The analyses were conducted at the Chemical Engineering Laboratory, Jessore University of Science and Technology, Bangladesh and at the laboratory of Asia Arsenic Network, Jessore, Bangladesh using standard methods.

Temperature distributions (inside and outside of the system) were measured at four different points as shown in Fig. 2. The amount of distilled water was measured every hour during the experiment. However, the field experiments were conducted on the roof of a five-storied academic building of Jessore University of Science and Technology between 24 April 2013 and 3 August 2013. The produced water was collected from 9:00 to 18:00 hrs.

\subsection{Parameters affecting productivity of the solar still}

There are various parameters affecting the productivity that include but not limited to solar intensity, ambient temperature, wind velocity, water temperature, temperature difference between water and cover, depth of water and salinity of water. Since the meteorological parameters (solar intensity, ambient temperature and wind velocity) cannot be controlled, we varied other parameters (water depth, salinity etc.) to find the variation in productivity of the solar still. 


\subsection{Efficiency improvement using absorber medium (glass marbles)}

Unconventional designs and techniques (using different solar energy absorbers e.g. violet dye, charcoal, black cotton cloth etc.) are reported to be useful for improvement of performance of solar stills [28-30]. A packed single layer of glass balls is reported to facilitate the heating operation of still water throughout the daytime and even after sunset [31]. In this research, the effect of using glass marbles as absorbing material was investigated.

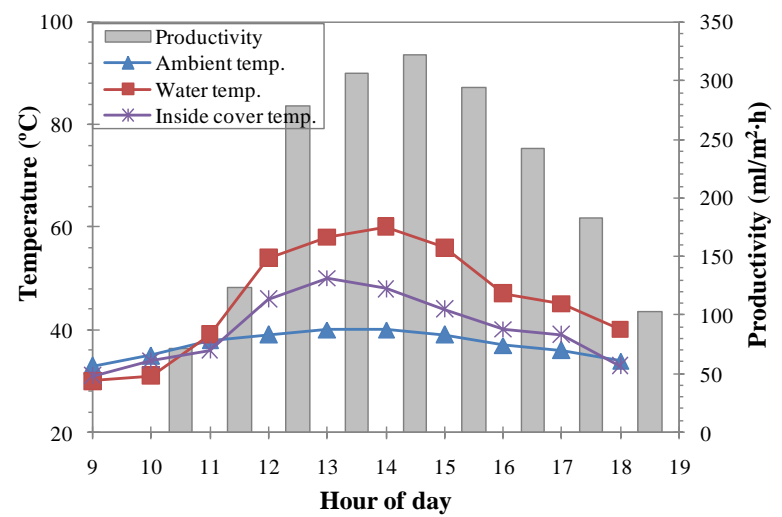

Fig. 3. Diurnal variation of temperature and water productivity. Condition: Tray area $=0.252 \mathrm{~m}^{2}$, Salt added $=0 \mathrm{~g}$, Water depth $=2.54 \mathrm{~cm}$.

\section{Results and Discussion}

\subsection{Diurnal variations of temperatures and production}

Effect of variation in temperatures (ambient, water, moist air and inside cover) on solar still productivity is thought to be crucial for understanding an economic design of the solar still. Malik et al. [11] proposed a theoretically whereas Badran [25] showed experimentally that temperatures at different locations of a solar still are vital parameters for productivity enhancement of a solar still. However, Fig. 3 shows the diurnal variations of temperatures at different locations of the still and cumulative production. Highest water temperature, inside cover temperature and ambient temperature were observed at the time between 13:00 to 14:00 hrs. This is due to the fact that the solar radiation is also highest at this time period [32]. It is also found that the water temperature was the maximum followed by inside cover temperature and ambient temperature, respectively. The inside cover temperature is less than that of water because the moist water travelled to the cover and released latent heat producing liquid water. Figure 3 also depicts the cumulative water production over the studied period. The production increases from the beginning and reaches maximum at 14:00 hrs and then starts to decrease. These plots clearly indicate that the productivity is influenced by the solar radiation intensity and thus by ambient, water and inside cover temperatures.

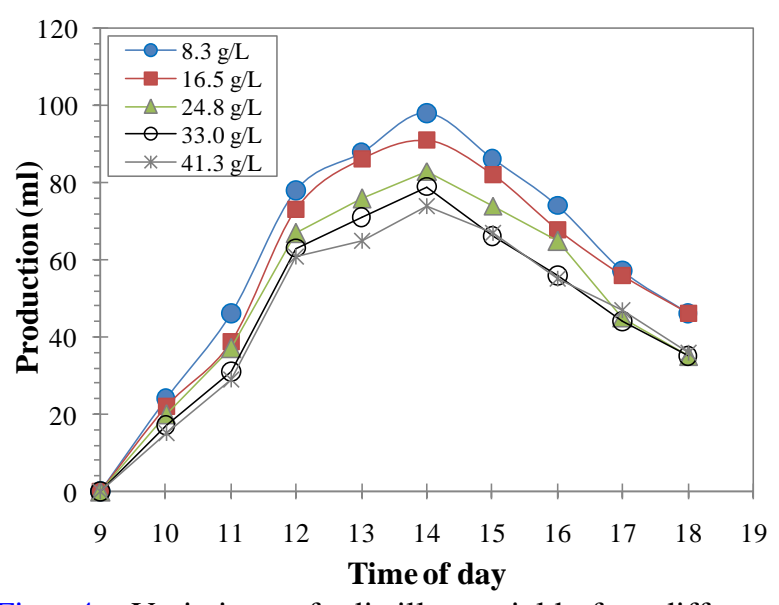

Fig. 4. Variation of distillate yield for different concentration of salt addition with respect to time of day. Condition: Tray area $=0.252 \mathrm{~m}^{2}$, Water depth $=$ $5.08 \mathrm{~cm}$.

\subsection{Effect of salinity of water}

Salt concentration is one of the important factors affecting the productivity of a solar still. Muftah et al. [8] and Sivakumar and Sundaram [27] reviewed techniques of solar still efficiency as well as various factors that are responsible for change in productivity and showed that salinity has a great effect on solar still productivity. Effect of salt concentration in the initial water was investigated and the result was depicted in Fig. 4, which showed that the production of the solar still decreases with the increases in salt concentration. Since the salinity of seawater varies from $30-40 \mathrm{~g}$ of salt per liter, the present result confirms that the seawater can be treated too with this solar still to obtain potable water. Such inverse relationship between water production and salt concentration may be explained with the surface tension of the brackish water contained initially in the still. Addition of salt increases the surface tension and hence decreases the rate of evaporation at a specific temperature. Similar results have been found by Rai et al., who studied experimental performances of a single basin solar still coupled with flat plate collector [33]. Even though the increase in salinity tends to increase the threat of corrosion damage to the components of the solar still, it requires different array of research that is out of scope of this present work.

\subsection{Effect of initial brine water depth on water production}

Initial water depth in the solar still is thought to actively influence the performance of a still [34]. It is one of the 


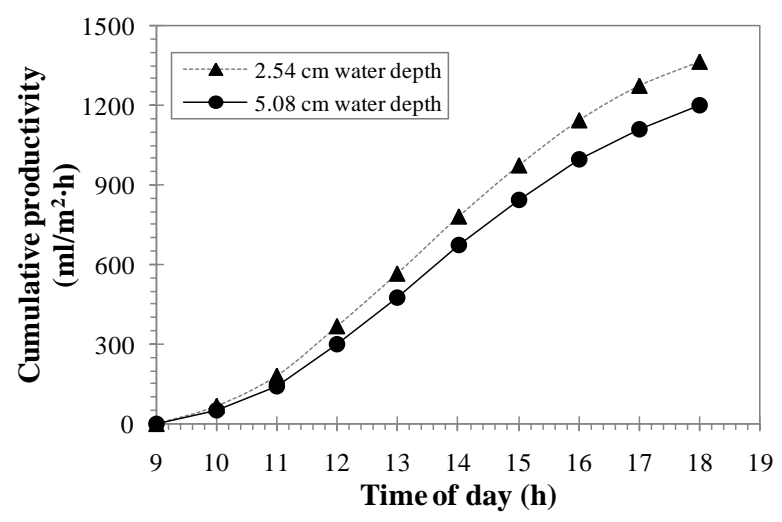

Fig. 5. Variation of cumulative productivity with respect to brine water depth inside the still. Condition: Tray area $=0.252 \mathrm{~m}^{2}$, Salt concentration $=8.3 \mathrm{~g} / \mathrm{L}$.

important parameters that affect the internal heat and mass transfer for solar still resulting the water production of the solar still [19,25]. Effect of brine water depth on water production was investigated by varying the brine depth and keeping all other conditions same. The results are depicted in Fig. 5 from where it is obvious that initial water depth in the solar still has an effect on water production. It is found from the figure that the productivity of the single-basin solar still increases by $13.7 \%$ with the decrease in brine water depth from 5.08 to $2.54 \mathrm{~cm}$. This can be attributed to the fact that higher heat absorption capacity of the water at lower water depth results to higher water temperature and consequently increase in evaporation rate. The obtained results in this research are in very good agreement with that obtained by Nafey et al. [35] and Ahsan et al. [36] who conducted experiments for finding out different parameters affecting the solar still productivity in Suez Gulf area and Malaysia, respectively.

\subsection{Solar still efficiency improvement}

Solar still efficiency was investigated by using glass marbles and the data are presented in Fig. 6 . Productivity by using marbles, solar energy absorbing material, superseded the productivity without using marbles throughout the observation period. This result indicated that glass marbles could absorb solar radiation at higher rate and facilitated the production of distilled water. It is obvious from the figure that volumetric production increased substantially, which can be attributed to the high absorbency of the glass marble.

The cumulative water production was depicted in Fig. 7. Quite expectedly the cumulative water production by using glass marbles was higher than that of without using marbles. The cumulative water production was calculated and 29\% increase in efficiency was observed. Although black ink [28], black rubber [28], inorganic salts e.g. $\mathrm{K}_{2} \mathrm{Cr}_{2} \mathrm{O}_{7}, \mathrm{KMnO}_{4}, \mathrm{CuSO}_{4}$ etc. [28,37] are reported to increase the solar still efficiency, locally available and cheap glass marble has initiated a huge scope of efficient water production for domestic use. It is obvious from the figure that volumetric production increased substantially, which was determined to be $29 \%$.

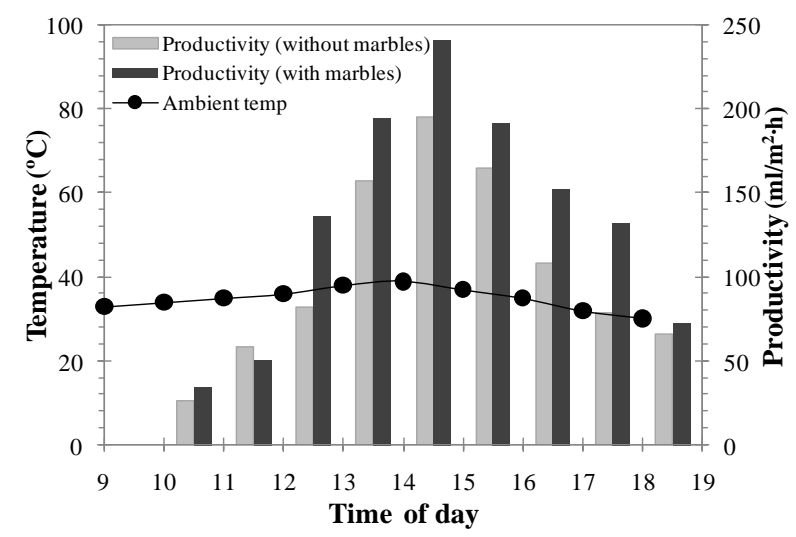

Fig. 6. Relationship among productivity, ambient temperature and time of day with and without using glass marble as energy absorbing material. Condition: Tray area $=0.252 \mathrm{~m}^{2}$, Water depth $=2.54 \mathrm{~cm}$.

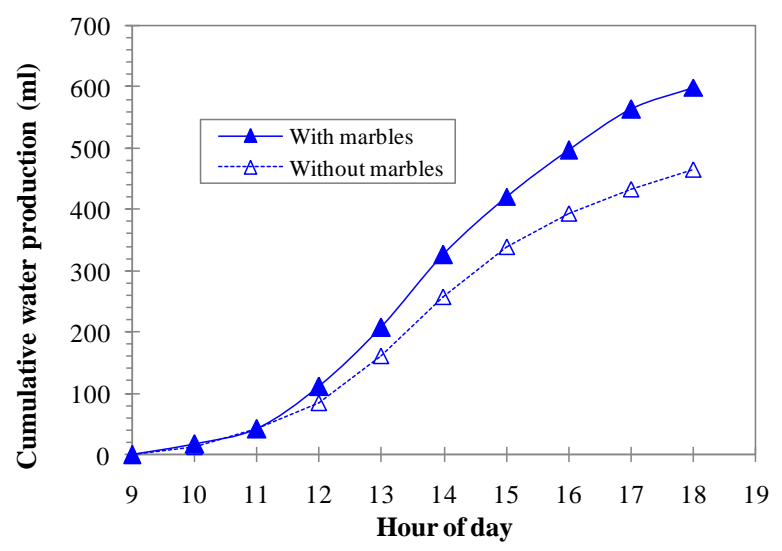

Fig. 7. Cumulative water production as a function of the hour of day. Condition: Tray area $=0.252 \mathrm{~m}^{2}$, Water depth $=2.54 \mathrm{~cm}$

\subsection{Quality parameters of distilled water}

Table 1 shows the tested results (quality parameters) of synthetic water before and after conducting experiment using the single-basin solar still. As it is seen, the $\mathrm{pH}$ value remains within the acceptable range. The salinity in terms of chloride concentration was also found to be $117-126 \mathrm{mg} / \mathrm{l}$, which is within the permissible limit of Bangladesh drinking water quality standards as well as WHO standards [38]. According to drinking water quality standards, the total dissolved solids (TDS) and total hardness are less than $600 \mathrm{mg} / \mathrm{l}$ and $500 \mathrm{mg} / \mathrm{l}$, respectively. From the test results of obtained water it is found that the measured TDS and total hardness remain under the standard values. Apart from that nitrate was found to be absent in the water and at the same time a faint odor was noticed in the present research due to use of polythene. 
Table 1. Tested results of distilled water obtained from the solar still.

\begin{tabular}{lccc}
\hline \multirow{2}{*}{ Parameter (unit) } & \multicolumn{2}{c}{ Synthetic water } & WHO drinking water quality \\
\cline { 2 - 3 } standards [38]
\end{tabular}

\subsection{Cost analysis}

Solar distillation is one of the most economical systems compared to the other distillation systems because of the cost-free energy from the sun as well as cheap materials of construction. Cost analysis of single basin solar still was carried out by measuring all costs of component used to construct the complete set of the solar still in this work. Table 2 shows total cost in Bangladesh currency (BDT) of two single-basin solar stills. Total cost was calculated to be BDT 690, which means that the construction cost of a single solar still is BDT 345. Since for the durability of the solar stills, a life of over four or five years cannot be guaranteed, a four of durability is commonly estimated [39]. Considering $4 \mathrm{y}$ of design life of the solar still $[39,40]$, the total production throughout this life is estimated to be 992.8 lit resulting production cost of water of BDT 0.35 per lit. Even though a universally comparable cost calculation is not possible because of different methods of cost estimation, different design aspects, different extent of per capita energy consumption at different localities and variation in price of materials, the cost calculated in this research is smaller than that estimated by Kumar and Tiwari [41] who used a glass-covered active solar still, Karima et al. [40] who produced water in potable solar still, and many other researchers.

Table 2. Cost analysis of two single-basin solar stills.

\begin{tabular}{lrr}
\hline Component & Amount & Cost (BDT) \\
\hline Wood plank & $3 \mathrm{~kg}$ & 60 \\
Hardboard & $1 \mathrm{~m}^{2}$ & 50 \\
Wire & $0.6 \mathrm{~kg}$ & 60 \\
Glass marbles & $160 \mathrm{dozens}$ & 250 \\
Polyethylene (white) & $2.1 \mathrm{~m}^{2}$ & 140 \\
Polyethylene (black) & $2.3 \mathrm{~m}^{2}$ & 45 \\
Miscellaneous & --- & 85 \\
\hline Total & & 690 \\
\hline
\end{tabular}

\section{Conclusions}

In this paper, the effects of several operational parameters (e.g. temperature, salinity, water depth, addition of heat absorbing material etc.) affecting the performance of low-cost and portable single-basin solar still have been investigated. It is obvious that the temperature is directly proportional to the production. The water production of the solar still is found to decrease with the increases in salt concentration. The brine water depth plays an important role and it is evident from the results that the water production increases with the decrease in water depth. The efficiency of the solar still increases with the addition of energy adsorbing material such as glass marbles. The obtained water quality parameters are within the ranges of drinking water standards prescribed by WHO.

Solar still is an attractive option and very good alternative for obtaining fresh and potable water for domestic use. In cases of natural disaster such as flood, cyclones, storm surges, river bank erosion etc. when drinkable water is not available to the most vulnerable people, it might be a potential alternative for water production in disaster-prone areas. The design and construction is straight forward so that it can be constructed and operated by anybody with a very little or even no technical skill. The system would render more competitiveness with other renewabledesalination technologies in small-scale water production.

\section{Acknowledgement}

The authors would like to acknowledge Md. Abu Shamim Khan, Chemist, Environmental Laboratory, Asia Arsenic Network, Jessore, Bangladesh for his kind assistance for measuring some quality parameters of water.

\section{REFERENCES}

[1] Website of World Population Review, http://worldpopulationreview.com/countries/banglades h-population/, (Website last visited on 12 April 2014).

[2] G.B. Avery Jr., J.D. Willey, R.J. Kieber, Diurnal variations in major rainwater components at a coastal site in North Carolina, Atmospheric Environment, 35 (2001) $3927-3933$.

[3] F.A. Abdullah, A.W. Al-Shareef, Roof rainwater harvesting systems for household water supply in Jordan, Desalination, 243 (2009) 195 - 207.

[4] B. Helmreich, H. Horn, Opportunities in rainwater harvesting, Desalination, 248 (2009) 118 - 124.

[5] H.P. Garg, H.S. Mann, Effect of climatic, operational and design parameters on the year-round performance of single-sloped and double-sloped solar stills under Indian arid zone conditions, Solar Energy, 18 (1976) $159-164$.

[6] J.A. Clark, The steady-state performance of a solar still, Solar Energy, 44 (1990) 43 - 49

[7] B.A. Akash, M.S. Mohsen, W. Nayfeh, Experimental study of the basin type solar still under local climate 
conditions, Energy Conversion and Management, 41 (2000) $883-890$.

[8] A.F. Muftah, M.A. Alghoul, A. Fudholi, M.M. AbdulMajeed, K. Sopian, Factors affecting basin type solar still productivity: A detailed review, Renewable and Sustainable Energy Reviews, 32 (2014) 430 - 447.

[9] G. Xiao, X. Wang, M. Ni, F. Wang, W. Zhu, Z. Luo, $\mathrm{K}$. Cen, A review on solar stills for brine desalination, Applied Energy, 103 (2013) 642 - 652.

[10] J.A. Duffie, W. Beckmann, Solar engineering of thermal process, $2^{\text {nd }}$ Ed., Wiley and Sons, NY, 1991.

[11] M.A.S. Malik, G.N. Tiware, A. Kumar, M.S. Sodha, Solar Desalination, Pergamon Press, Oxford, UK (1982).

[12] D. Mowla, G. Karimi, Mathematical modeling of solar stills in Iran, Solar Energy, 55 (1995) 389 - 393.

[13] M.A. Yaghoubi, A. Sabzevari, Calculation of the hourly output of a solar still for various cities in Iran, Renewable Energy, 7 (1996) 427 - 435.

[14] M. Abdelkader, A.S. Nafy, A. Abdelmotalip, A.A. Mabrouk, Experimental evaluation of solar still mathematical models, In: Fourth International Water Technology Conference, Alexandria, Egypt (1999) 197 $-203$.

[15] A.A. Al-Karaghouli, W.E. Alnaser, Performances of single and double basin solar-stills, Applied Energy, 78 (2004) $347-354$.

[16] A. Ahsan, A. Rahman, A. Shanableh, N.N. Nik Daud, T.A. Mohammed, A.N.A. Mabrouk, Life cycle cost analysis of a sustainable solar water distillation technique, Desalination and Water Treatment, 51 (2013) $40-42$.

[17] S.K. Nandi, M.N. Hoque, H.R. Ghosh, S.K. Roy, Potential of wind and solar electricity generation in Bangladesh, International Scholarly Research Network Renewable Energy, 2012 (doi: 10.5402/2012/401761).

[18] H. Al-Hinai, M.S. Al-Nassri, B.A. Jubran, Parametric investigation of a double-effect solar still in comparison with a single-effect solar still, Desalination, 150 (2002) $75-83$.

[19] R. Tripathi, G.N. Tiwari, Effect of water depth on internal heat and mass transfer for active solar distillation, Desalination, 173 (2005) 187 - 200.

[20] A.J.N. Khalifa, A.M. Hamood, Effect of insulation thickness on the productivity of basin type solar stills: An experimental verification under local climate, Energy Conversion and Management, 50 (2009) 2457 -2461 .

[21] S. Kumar, G.N. Tiwari, H.N. Singh, Annual performance of an active solar distillation system, Desalination, 127 (2000) $79-88$.

[22] K.B. Baibutaev, B.M., Achilov, G. Kamaeva, Effect of the salt content of water on evaporation in solar stills, Geliotekhnika, 2 (1970) 83.

[23] A.S. Nafey, M.A. Mohamad, M.A. Sharaf, Enhancement of solar water distillation process by surfactant additives, Desalination, 220 (2008) 514 523.

[24] G.C. Pandey, Effect of dried and forced air bubbling on the partial pressure of water vapour and the performance of solar still, Solar Energy, 33 (1984) 13 -18 .
[25] O.O. Badran, Experimental study of the enhancement parameters on a single slope solar still productivity, Desalination, 209 (2007) 136 - 143.

[26] K.J. Hanson, The radiative effectiveness of plastic films for greenhouses, U.S. Weather Bureau, Washington D.C., 1963.

[27] V. Sivakumar, E.G. Sundaram, Improvement techniques of solar still efficiency: A review, Renewable and Sustainable Energy Reviews, 28 (2013) 246 - 264.

[28] B.A. Akash, M.S. Mohsen, O. Osta, Y. Elayan, Experimental evaluation of a single-basin solar still using different absorbing materials, Renewable Energy, 14 (1998) 307 - 310.

[29] M.M. Naim, M.A.A.E. Kawi, Non-conventional solar stills Part 1. Non-conventional solar stills with charcoal particles as absorber medium, Desalination, 153 (2002) $55-64$

[30] S. Nijmeh, S. Odeh, B. Akash, Experimental and theoretical study of a single-basin solar still in Jordan, International Communications in Heat and Mass Transfer, 32 (2005) $565-572$

[31] Z.S. Abdel-Rehim, A. Lasheen, Improving the performance of solar desalination systems, Renewable Energy, 30 (2005) 1955 - 1971.

[32] I. Khan, P.K. Halder, N. Paul, Renewable energy based hybrid nano-power station for remote isolated island, In: Proceedings of $4^{\text {th }}$ Global Engineering, Science and Technology Conference, BIAM Foundation, Dhaka, Bangladesh, 27 - 28 December, 2013.

[33] S.N. Rai, D.K. Dutt, G.N. Tiwari, Some experimental studies of a single basin solar still, Energy Conversion and Management, 30 (1990) 149 - 153.

[34] A. Ghoneyem, Experimental study on the effects of the cover and numerical prediction of a solar still output, MS Thesis, Middle East Technical University, Ankara, Turkey, 1995.

[35] A.S. Nafey, M. Abdelkader, A. Abdelmotalip, A.A. Mabrouk, Parameters affecting solar still productivity, Energy Conversion \& Management, 41 (2000) 1797 1809.

[36] A. Ahsan, M. Imteaz, U.A. Thomas, M. Azmi, A. Rahman, N.N.N. Daud, Parameters affecting the performance of a low cost solar still, Applied Energy, 114 (2014) $924-930$.

[37] M. A. Jamal, T.M.H. Junaidi, J.A. Muaddi, A step forward towards an ideal absorber for solar energy, International Journal of Energy Research, 15 (1991) $367-375$.

[38] WHO, Guidelines for drinking water quality, $4^{\text {th }}$ Edition, 2011.

[39] P. Wassouf, T. Peska, R. Singh, A. Akbarzadeh, Novel and low cost designs of portable solar stills, Desalination, 276 (2011) 294 - 302.

[40] A. Karima, Mitul, K.M. Shafiul Islam, Desalination using low cost tubular solar still, Proceeding of the International Conference on Engineering Research, Innovation and Education, SUST, Sylhet, Bangladesh, 11 - 13 January, 2013.

[41] S. Kumar, G.N. Tiwari, Life cycle cost analysis of single slope hybrid (PV/T) active solar still, Applied Energy, 86 (2009) 1995 - 2004. 